\title{
Special issue in honor of Harris Schlesinger: New developments in the study of risk preferences
}

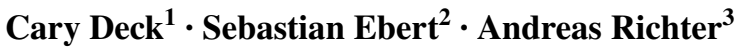

Published online: 3 May 2018

(C) International Association for the Study of Insurance Economics 2018

Following a long illness, Harris Schlesinger died on September 29, 2015. This special issue of the Geneva Risk and Insurance Review along with a companion issue of the Journal of Risk and Insurance honors his legacy to the field of risk and insurance economics. Three of the papers in this issue were presented at the 2016 CEAR/ MRIC Behavioral Insurance Workshop in Munich, which was held in honor of Harris, as he had contributed tremendously to starting and establishing this workshop series.

Harris's death has been a huge loss for the research community. Harris was a leading researcher in his field and continued to make important contributions until his death, including delivering the EGRIE keynote address, which is published in the Geneva Risk and Insurance Review, March (2015), volume 40(1). More generally, Harris was an inspiring leader for the community of risk and insurance economists and an especially supportive mentor for young researchers.

Harris and Henri Loubergé founded the Geneva Papers on Risk and Insurance Theory in 1990, which is now the Geneva Risk and Insurance Review (GRIR). Harris co-edited the journal from 1990 to 1998 . He was an avid champion of the

Sebastian Ebert

s.ebert@fs.de

Cary Deck

cdeck@cba.ua.edu

Andreas Richter

richter@bwl.lmu.de

1 Culverhouse College of Commerce, University of Alabama, 361 Stadium Dr., Tuscaloosa, AL 35487, USA

2 Frankfurt School of Finance and Management, Adickesallee 32-34, 60322 Frankfurt am Main, Germany

3 Institut für Risikomanagement und Versicherung, LMU München, Schackstraße 4/III, Zi. 305, 80539 München, Germany 
European Group of Risk and Insurance Economists (EGRIE) and was president in 2006-2007. Harris also served as President of the American Risk and Insurance Association (1997-1998), a member of its Board of Directors (1991-1998), and held editorial positions on its flagship journal, the Journal of Risk and Insurance. Given the importance of Harris Schlesinger's contribution to the risk and insurance economics community, it was decided that both the Geneva Risk and Insurance Review and the Journal of Risk and Insurance would jointly dedicate special issues in his honor in appreciation of Harris's impact on the academic community.

This special issue of the Geneva Risk and Insurance Review in honor of Harris Schlesinger features five articles. A major theme in Harris's work is behavior under risk within the expected utility model. In the first article of this issue, Gollier and Kimball (2018) provide several fundamental results on this matter. The authors study two general types of risk comparisons, which are referred to as being "contingent" and "non-contingent" (on a reference lottery), respectively. The authors illustrate the economic relevance of each risk comparison, clarify their relationship, and propose a general solution concept to problems involving these comparisons using the "basis" approach. While the basis approach has often been used implicitly, the current paper makes a methodological contribution by making the basis approach itself as well as the range of its application explicit.

Ambiguity is a condition where the probabilities of possible events are not uniquely assigned. Harris contributed to our understanding of the effects of ambiguity on optimal behavior (Osaki and Schlesinger 2014a, b) and of its experimental measurement including higher-order ambiguity preferences (Baillon et al. 2018). When decision-makers are averse to ambiguity, they value information that reduces it (Snow 2010), although the process of acquiring information may actually increase ambiguity, for example, due to the uncertainty of which (genetic) test results will be obtained (Hoy et al. 2014). Nocetti (2018) presents a model that facilitates the distinction between posterior uncertainty over the correct probability distribution and uncertainty over the message that will be received from a given message service. This allows to integrate the existing results by identifying attitudes towards both sources of ambiguity separately. In such a more general model, the comparative statics of the value of information under ambiguity resemble the comparative statics of the value of information under risk to a much larger degree.

"A well-known result in the insurance literature states that a risk averter who is offered insurance at a 'fair' price will choose to fully insure." Doherty and Schlesinger (1990, p. 243). But Schlesinger and Schulenburg (1987) and Doherty and Schlesinger (1990) show that this holds only when there is no risk of default by the insurer. In those papers, Harris and his respective coauthors assume that the individual's behavior is characterized by expected utility theory. Harrison and $\mathrm{Ng}$ (2018) use experiments to examine this setting. They find that allowing for non-expected utility preferences by participants suggests that welfare loss is not as significant as when all participants are assumed to have expected utility preferences.

Courbage et al. (2018) contribute an article on higher-order risk preferences, an area of research that was significantly advanced by Harris. The authors derive new properties of the $N$ th-order utility premium that was also examined in one of Harris's most recent articles, Ebert et al. (2017). The Nth-order utility premium 
measures the pain associated with facing the passage of one risk to a more severe risk. The authors analyze the superadditivity of the $N$ th-order utility premium and relate it to concepts such as mixed risk aversion (Caballé and Pomansky 1996), a preference for combining good with bad (Eeckhoudt et al. 2009), or risk apportionment (Eeckhoudt and Schlesinger 2006).

In the final article of this issue, Bostian and Heinzel (2018) also investigate higher-order risk effects. But, unlike most articles on higher-order risk preferences, the authors study them in a recursive utility framework rather than in the classical expected utility model. This way, the authors connect to one of Harris's later interests - the study of higher-order risk preferences in general decision making models (e.g., Eeckhoudt et al. 2018). Bostian and Heinzel investigate comparative precautionary saving under increases in income risk and increases in risk on the saving return, and provide conditions that ensure a stronger precautionary motive.

In addition to these articles, we strongly recommend that all readers of this special issue also read the special issue of The Journal of Risk and Insurance (2018 June issue, vol. 85, no. 2) in honor of Harris Schlesinger, edited by Christian Gollier and Louis Eeckhoudt.

It has been an honor for us to serve as guest editors of this special issue in honor of Harris Schlesinger. We wish to thank all the authors as well as the referees for the hard work on the submissions. We also thank Harris for all he has meant to us.

\section{References}

Baillon, A., H. Schlesinger, and G. van de Kuilen. 2018. Measuring higher order ambiguity preferences. Experimental Economics 21: 233-256.

Bostian, AJ.A., and C. Heinzel. 2018. Comparative precautionary saving under higher-order risk and recursive utility. The Geneva Risk and Insurance Review. https://doi.org/10.1057/s1071 3-018-0030-2.

Caballé, J., and A. Pomansky. 1996. Mixed risk aversion. Journal of Economic Theory 71: 485-513.

Courbage, C., H. Loubergé, and B. Rey. 2018. On the properties of high-order non-monetary measures for risks. The Geneva Risk and Insurance Review. https://doi.org/10.1057/s10713-018-0029-8.

Doherty, N.A., and H. Schlesinger. 1990. Rational insurance purchasing: Consideration of contract nonperformance. Quarterly Journal of Economics 105: 243-253.

Ebert, S., D.C. Nocetti, and H. Schlesinger. 2017. Greater mutual aggravation. Management Science. https://doi.org/10.1287/mnsc.2017.2746.

Eeckhoudt, L., Laeven, R.J.A., and H. Schlesinger. 2018. Risk apportionment: The dual Story. Working Paper.

Eeckhoudt, L., and H. Schlesinger. 2006. Putting risk in its proper place. American Economic Review 96: $280-289$.

Eeckhoudt, L., H. Schlesinger, and I. Tsetlin. 2009. Apportioning of risks via stochastic dominance. Journal of Economic Theory 144: 994-1003.

Gollier, C. and M. Kimball. 2018. New methods in the classical economics of uncertainty: Comparing risks. The Geneva Risk and Insurance Review. https://doi.org/10.1057/s10713-018-0026-y.

Harrison, G., and J.M. Ng. Welfare effects of insurance contract non-performance. The Geneva Risk and Insurance Review. https://doi.org/10.1057/s10713-018-0024-0. 
Hoy, M., R. Peter, and A. Richter. 2014. Take-up for genetic tests and ambiguity. Journal of Risk and Uncertainty 48: 111-133.

Nocetti, D.C. 2018. Ambiguity and the value of information revisited. The Geneva Risk and Insurance Review. https://doi.org/10.1057/s10713-018-0025-z.

Osaki, Y. and H. Schlesinger. 2014a. Portfolio choice and ambiguous background risk. Working Paper, Tuscaloosa: University of Alabama.

Osaki, Y. and H. Schlesinger. 2014b. Precautionary saving and ambiguity. Working Paper, Tuscaloosa: University of Alabama.

Schlesinger, H., and J.M.G. vd Schulenburg. 1987. Risk aversion and the purchase of risky insurance. Journal of Economics (Zeitschrift für Nationalönomie) 47: 309-314.

Snow, A. 2010. Ambiguity and the value of information. Journal of Risk and Uncertainty 40: 133-145. 